\title{
The Correlation between Discipline and Work Productivity at PT. Bina Megah Indowood
}

\section{Hubungan antara Kedisiplinan dan Produktivitas Kerja PT Bina Megah Indowood}

\author{
Devy Syanindita Roshida, Indriati Paskarini \\ Departmentof Occupational Safety and Health, Faculty of Public Health, Universitas Airlangga \\ Campus C Mulyorejo, Surabaya East Java 60115 Indonesia
}

\begin{abstract}
Introduction: Productive human resources are able to complete the given tasks and responsibilities well. Discipline is the mental attitude at work needed to achieve productivity. Discipline at work creates smooth operational activities of the company. PT. Bina Megah Indowood is a manufacturing company that provides solid wood flooring with various thickness. The present study analyses $\neg$ the correlation between individual characteristics, discipline, and work productivity among molding machine workers of PT. Bina Megah Indowood. Methods: This study was an observational analytic study with a cross sectional approach. Variables in this study were work discipline as an independent variable and productivity as a dependent variable. The population in this study were 58 workers in the molding section, 50 of whom were taken as samples. The sampling technique used was a simple random sampling. Morover, the two types of data used in this study were primary data obtained from questionnaires and secondary data obtained from the company profiles and a summary of production results every month. The technique of data analysis data was a Spearman correlation test. Results: Most workers in the molding machine production unit of PT. Bina Megah Indowood have moderate discipline and moderate work productivity. There is a correlation between discipline and work productivity with $\rho$-value $=0.020$. The contingency coefficient between discipline and work productivity is 0.328 , which means the correlation is weak. Conclusion: Higher work productivity is followed higher level of discipline. Meanwhile, individual characteristics have no correlation with work productivity because the distribution resultof individual characteristics is only dominant in one category.
\end{abstract}

Keywords:discipline, individual characteristics, work productivity

\begin{abstract}
ABSTRAK
Pendahuluan: Sumber daya manusia produktif akan bertanggung jawab dan menyelesaikan tugas yang telah dibebankan. Kedisiplinan adalah sikap mental dalam bekerja yang dibutuhkan untuk mencapai produktivitas. Bekerja dengan disiplin mampu menciptakan kelancaran kegiatan operasional perusahaan. Tujuan penelitian ini yaitu menganalisis hubungan antara karakteristik individu, kedisiplinan dengan produktivitas pekerja mesin moulding unit produksi PT. Bina Megah Indowood. Metode: Penelitian ini menggunakan pendekatan cross sectional dengan metode observasional analitik. Variabel penelitian ini adalah kedisiplinan dan produktivitas kerja. Besar populasi pada penelitian ini berjumlah 58 pekerja dan sampel penelitian berjumlah 50 pekerja mesin moulding. Teknik pengambilan sampel penelitian ini menggunakan simple random sampling. Terdapat dua jenis data yaitu data primer dan data sekunder. Data primer didapatkan dengan pengisian kuesioner oleh responden dan data sekunder didapatkan dari perusahaan berupa profil perusahaan, proses produksi, data jumlah pekerja dan rekap hasil produksi setiap bulan. Teknik analisis data menggunakan uji korelasi Spearman. Hasil: Penelitian menunjukkan hasil terdapat hubungan antara kedisiplinan dan produktivitas kerja dengan $\rho$-value $(\rho=0,020)$. Koefisien kontingensi antara disiplin dan produktivitas kerja yatu 0,328 yang berarti korelasi tersebut lemah. Simpulan: Terdapat hubungan antara kedisiplinan dengan produktivitas kerja. Peningkatkan produktivitas kerja diikuti dengan peningkatan kedisiplinan. Sedangkan, karakteristik individu tidak berhubungan dengan produktivitas kerja karena hasil distribusi karakteristik individu dominan hanya pada satu kategori.
\end{abstract}

Kata kunci: kedisiplinan, karakteristik individu, produktivitas kerja

Corresponding Author:

Devy Syanindita Roshida

Email: devy.syanindita.roshida-2016@fkm.unair.ac.id

Telephone: +6287702705688

\section{INTRODUCTION}

Human resources lead to an important role as the main driver of company's operational activities in achieving its goals, both for profits and for survival of a company. A company can maintain 
its existence by the support of human resources it has. Thus, a company's labor problem is one of the serious problems that needs big attention (Jamaludin, 2018)

Human resource management is highly important for a company in managing and utilizing the workforce so that it can function properly in accordance with the company's goals. Manpower is a resource who have an important role in the company's operational activities. Thus, workers are expected to be skilful in performing their jobs. Company resources require an appropriate management process in order to create a balance between the ability of the workforce and the demands of the company (Hasibuan, 2010).

Discipline is one of the influential factors in human resources. Work discipline can bring great benefits, both for the company and for employees. For companies, the presence of work discipline will create a smooth implementation of each task, so workers can have optimal results, and company's goals will be achieved. For employees, work disicipline will create a pleasurable atmosphere, so it will improve morale in carrying out the work. Thus, the workers can develop energy and mind as much as possible to achieve the goals and targets set by the company. If the working environment is all disciplined, then an employee will be disciplined, but if the company's work environment is not disciplined, then an employee will also be undisciplined. For this reason, it is very difficult for an undisciplined work environment to apply discipline because the work environment will be a role model for the employees (Liyas and Primadi, 2017).

An employee must be as effective and efficient as possible in doing his job. The quality and quantity of employees must be in accordance with the needs of the company, and the placement of workers must also be appropriate with their expertise. Thus, the spirit of work and work discipline will be better and more effective to support the realization of company's goals (Syafrina, 2017).

Producing productive and competent workers is not the only step that companies should perform to achieve their goals. Another important step is the increase in worker productivity. Productive human resources can design and apply all jobs in accordance with the goals or targets of the company. Human resources are called productive if they can complete the tasks and responsibilities on time (Firdaus, 2019).
Based on the report of the World Economic Forum (2018) Indonesia's global competitiveness index in 2018 rose to rank 36 from rank 41. Competitiveness is measured by 12 pillars, namely institutions, infrastructure, macroeconomic environment, health services and primary education, training and higher education, goods market efficiency, labor market efficiency, development of financial market, technological readiness, market size, business sophistication, and innovation (World Economic Forum, 2018)

Based on the Asian Productivity Organization (APO), which was published in September 2018, the productivity of Indonesian workers ranks 11th out of 20 APO member countries and at the ASEAN level, the productivity of Indonesian workers ranks 4th. In terms of competitiveness, Indonesia ranks 36th among 137 countries. As for the ASEAN level, Indonesia ranks 4th among the 9 ASEAN countries listed in the 2017-2018 Global Competitiveness Report (Asian Productivity Organization, 2018)

Work productivity has an important meaning as a way of life and mental attitude of all workers. With productivity, workers always try to improve a better quality of their life every day. This provides encouragement for workers to try and increase productivity in doing the given work. Therefore, workers' productivity needs to get serious attention from company leaders as it can make employees easier to improve and increase their productivity (Siswadi, 2016)

In addition, work productivity is defined as a comparison between the input or use of resources with the output or outputs issued. Therefore, productivity has two dimensions: effectivity and efficiency. Effectivity is a matter related to the achievement of targets that have been set, while efficiency refers to the use of minimum resources with maximum results. Factors that can influence the level of work productivity include motivation, discipline, work ethic, skills and education (Sedarmayanti, 2011).

A company needs the application of work discipline to increase work productivity in order to achieve the stated company goals. The progress of the company can be seen from the level of employee discipline in carrying out their duties. For the smooth implementation of duties in ensuring the maintenance of order and correcting and educating workers who make mistakes, the company should make regulations regarding discipline, which regulate obligations, prohibitions and sanctions that 
apply during the work process ( Idris, Hasibuan, and Efriza, 2017).

One of the factors affecting work productivity is discipline. Discipline is a reflectionof the actions and behavior of individuals, groups or communities in the form of compliance with applicable regulations, ethics and norms. Discipline can also be interpreted as self-control not to do something that is in conflict with the Pancasila morals. Discipline can reflect a successful human being because he is able to regulate and control himself regarding the procedures for work. Thus, there is a close relationship between successful people and disciplined individuals. In addition, there is also a close correlation in discipline and productivity. Discipline has a central role in shaping work patterns and productive work ethics (Sedarmayanti, 2011).

Achieving company goals requires discipline so that the work productivity of each individual can be increased, which will ultimately increase overall work productivity. Discipline can also maintain the mental attitude and character of each individual to respond and understand the task and responsibilities at work. All of the the company's efforts in striving for discipline will lead to the achievement of workers' work productivity (Sunarsi, 2018).

PT. Bina Megah Indowood (BMI) is a private company established in 2007 and is engaged in the manufacture of wood with the main product in the form of wood decking. It produces products from processed Merbau wood, Nail wood, Sika Teak wood and Sonokeling wood. PT. Bina Megah Indowood has become a major wood flooring manufacturer with a wide export range to Asia, Australia, Africa and Europe. This company provides high quality solid wood flooring with the desired thickness to meet various needs. The company's vision is to become a timber manufacturing industry that supplies good quality products throughout the world, taking advantage of the best quality of Indonesian wood through continuous efforts, which are made to improve the products and the ability to react quickly to market trends and demands.

The wood production process begins with a band saw process for the basic formation of logs. The second stage is the kiln dry, which is the process of storing wood at a certain temperature to eliminate the water content in the wood. The third stage is a single ripsaw, which is the process of smoothing wood surfaces. The fourth stage is the double planner, which is the process of forming the width of the wood to the desired thickness. The fifth stage is cross cut, which is the process of forming the length of the wood as desired. The sixth stage is molding, which is the process of forming the edge of the wood so that it can be linked to other woods. The last stage is finishing, which is the process of coating the wood with a sheet so that the color of the wood looks more contrasting and produces high quality wood. After all these processes are finished, the wood is packed and ready for sale.

Based on the interview with the head of the production unit, there are two kinds of problems faced by PT. Bina Megah Indowood, namely external and internal problems. An external problem is the long process of receiving raw materials because they are hindered by the long distance. Raw materials are received using inter-island expeditions using sea routes. So, if the receipt of raw materials is not timely, the production process is hampered. Meanwhile, internal problems include factors of workforce behavior of discipline, seriousness, speed and accuracy at work. Of the possible internal problems, the researchers are interested in examining the correlation between the discipline level of workers and work productivity.

The respondents in this study were workers in the molding machine production unit at PT. Bina Megah Indowood. This selection is based on the target set - calculated from the capacity of the machine during working hours that researchers can see and calculate the respondent's productivity. The calculation was obtained by comparing the capacity of the machine for one working day, and the results of the products produced.

\section{METHODS}

This research was an observational study since there was no intervention or specific treatment given to the object of research. The method used was an analytic method by examining the correlation of discipline and work productivity. The research approach was cross sectional as the data collection was taken at one period of time. This study was conducted from December 2019 to January 2020. This study has also received a certificate of ethical approval Number 221/EA/KEPK/2019.

The population of the study was workers of the molding machine production unit of PT. Bina Megah Indowood. The total population was 58 workers with a total sample of 50 workers. Samples were taken using a simple random sampling technique.

The research variables were divided into two categories, which were dependent and independent variables. Work productivity served as a dependent 
variable while discipline served as an independent variable.

The data were collected from two sources, primary and secondary data. The primary data were obtained from molding machine workers in the production unit of PT. Bina Megah Indowood by having them fill out the questionnaires, while the secondary data were obtained from the company profiles, production processes, employee data, and company achievement data.

The instruments that were used in this research were disciplinary questionnaires from Veitzhal (2011) with Pearson correlation value $>0.3$ and Cronbach's alpha reliability value $=0.915$, containing 13 questions with 5 indicators. The research data were then processed using a Spearman correlation test. The analysis was carried out to examine the relationship between variables in the form of a cross tabulation table. In addition, the analysis was done to see the strength between these variables.

\section{RESULTS}

\section{Individual Characteristics of Molding Machine Workers of PT. Bina Megah Indowood}

Individual characteristics in this study include age, length of work and last education. The distribution for each characteristic is described in Tables 1.

Table 1. Distribution of Age, Length of Work and Education of Workers in the Molding Machine Production Unit of PT Bina Megah Indowood in 2019

\begin{tabular}{lcc}
\hline & Frequency (n) & Percentage (\%) \\
\hline Age (Years) & 41 & 82 \\
$18-34$ & 8 & 16 \\
$35-51$ & 1 & 2 \\
$52-68$ & 50 & 100 \\
\hline Total & & \\
\hline Working Period (Years) & 30 & 60 \\
$1-4$ & 13 & 26 \\
$5-9$ & 7 & 14 \\
$10-13$ & 50 & 100 \\
\hline Total & & \\
\hline Education & 6 & 12 \\
JHS & 42 & 84 \\
SHS & 2 & 4 \\
Bachelor & 50 & 100 \\
\hline Total & &
\end{tabular}

Table 1 reflects the age distribution of workers in 2019. Age in this research is calculated from the time the workers were born until the research was conducted. Most of the workers (82\%) are 18-34 years old, $16 \%$ of the workers are $35-61$ years old, and $2 \%$ of the workers are $52-61$ years old.

The length of work is the calculated from the first time the workers worked at the company to the time the research was conducted. The majority of workers $(60 \%)$ have worked for $1-4$ years, $26 \%$ of workers have worked for 5-9 years, and $14 \%$ of workers have worked for 10-13 years. The majority of workers $(84 \%)$ graduated from senior high school, $12 \%$ of workers graduated from junior high school, and $4 \%$ of workers graduated from Bachelor.

\section{Employee Discipline in the Molding Machine Production Unit of PT. Bina Megah Indowood}

Discipline is an attitude or willingness to accept and obey the rules that are applied in the company. Discipline data were obtained through questionnaires filledby each production unit molding machine worker. Discipline in this study is classified into three categories which are low, moderate and high discipline.

Table 2 is the distribution of the discipline of molding machine workers of PT. Bina Megah Indowood. The table above shows that most workers $(82 \%)$ have moderate discipline, $8 \%$ have low discipline, and $10 \%$ have high discipline.

\section{Employee Productivity in the Molding Machine Production Unit of PT. Bina Megah Indowood}

The company's productivity is targeted from the capacity of the machine used in hours with the volume of wood that the company targets. This is compared with the number of products produced in one workday. The calculation results show that the productivity is grouped into three categories, namely low productivity, medium productivity, and high productivity.

Table 3 is the productivity distribution of the workers at the the molding machine production unit

Table 2. Discipline Distribution of Workers in the Molding Machine Production Unit of of PT. Bina Megah Indowood in 2019

\begin{tabular}{lcc}
\hline \multicolumn{1}{c}{ Discipline } & Frequency (n) & Percentage (\%) \\
\hline Low & 4 & 8 \\
Moderate & 41 & 82 \\
High & 5 & 10 \\
\hline Total & 50 & 100 \\
\hline
\end{tabular}


of PT. Bina Megah Indowood. From the table above, most workers $(52 \%)$ have moderate productivity, and the rest (48\%) have low productivity. There are no workers with high productivity.

\section{Correlation between Individual Characteristics and Productivity of Workers in the Molding Machine Production Unit of PT. Bina Megah Indowood}

The individual characteristics in this study include age, length of work, and last education based on low, medium and high productivity. Table 4 is a cross tabulation table between age and productivity of workers in the molding machine production unit of PT. Bina Megah Indowood. The table shows the result of the statistical test using the Spearman test with the resultof the Sig. (2-tailed) $=0.113$. This value is more than $\alpha(0.05)$. Thus, Ho is accepted, which means there is no correlation between age and productivity of the workers in the molding machine production unit of PT. Bina Megah Indowood.

Table 5 is a cross tabulation table between length of work and productivity of workers in the molding machine production unit of PT. Bina Megah Indowood. The table shows the result of the statistical test using the Spearman test with the resultof the Sig. $(2$-tailed $)=0.694$. This value is

Table 3. Distribution of Productivity of the workers in the Molding Machine Production Unit of PT. Bina Megah Indowood in 2019

\begin{tabular}{ccc}
\hline Productivity & Frequency (n) & Percentage (\%) \\
\hline Low & 24 & 48 \\
Moderate & 26 & 52 \\
\hline Total & 50 & 100 \\
\hline
\end{tabular}

Table 4. Correlation of Age and Productivity of Workers in the Molding Machine Production Unit of PT. Bina Megah Indowood in 2019

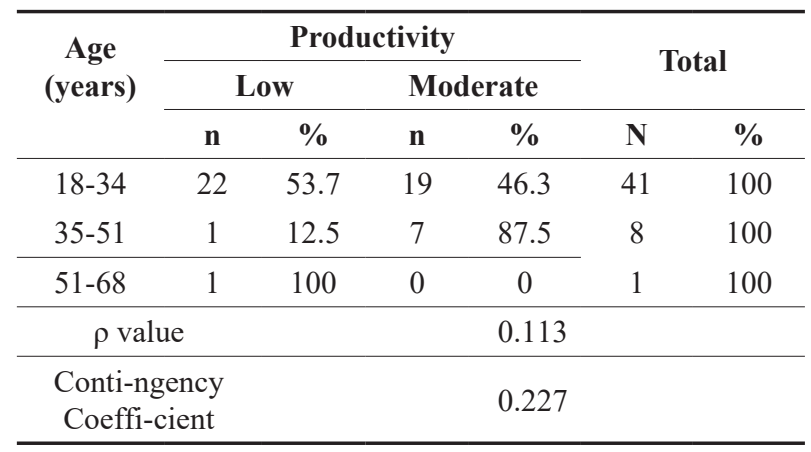

more than $\alpha(0.05)$ Thus, Ho is accepted, which means thereis no correlation between length of work and productivity of the workers in the molding machine production unit of PT. Bina Megah Indowood.

Table 6 is a cross tabulation table between education and productivity of workers in the molding machine production unit of PT. Bina Megah Indowood. The table shows the result of the statistical test using the Spearman test with the result of the Sig. $(2$-tailed $)=0.163$. This value is more than $\alpha(0.05)$. Thus, Ho is accepted, which means there is no correlation between education and productivity of the workers in the molding machine production unit of PT. Bina Megah Indowood.

Correlation between Discipline and Productivity of Workers in the Molding Machine Production Unit of PT. Bina Megah Indowood

Discipline is divided into three categories, namely low, medium and high discipline based

Table 5. Correlation between Length of Work and Productivity of Workers in the Molding Machine Production Unit of PT. Bina Megah Indowood in 2019

\begin{tabular}{|c|c|c|c|c|c|c|}
\hline \multirow{3}{*}{$\begin{array}{c}\text { Wor k } \\
\text { Period } \\
\text { (Years) }\end{array}$} & \multicolumn{4}{|c|}{ Productivity } & \multirow{2}{*}{\multicolumn{2}{|c|}{ Total }} \\
\hline & \multicolumn{2}{|c|}{ Low } & \multicolumn{2}{|c|}{ Moderate } & & \\
\hline & n & $\%$ & n & $\%$ & $\mathbf{N}$ & $\%$ \\
\hline $1-4$ & 16 & 53.3 & 14 & 46.7 & 30 & 100 \\
\hline $5-9$ & 3 & 23.1 & 10 & 76.9 & 13 & 100 \\
\hline $10-13$ & 5 & 71.4 & 2 & 28.6 & 7 & 100 \\
\hline \multicolumn{2}{|c|}{$\rho$ value } & \multicolumn{5}{|c|}{0.694} \\
\hline \multicolumn{2}{|c|}{$\begin{array}{l}\text { Conti-ngency } \\
\text { Coeffi-cient }\end{array}$} & \multicolumn{5}{|c|}{0.057} \\
\hline
\end{tabular}

Table 6. Correlation of Education and Productivity of Workers in the Molding Machine Production Unit of PT. Bina Megah Indowood in 2019

\begin{tabular}{|c|c|c|c|c|c|c|}
\hline \multirow{3}{*}{ Education } & \multicolumn{4}{|c|}{ Productivity } & \multirow{2}{*}{\multicolumn{2}{|c|}{ Total }} \\
\hline & \multicolumn{2}{|c|}{ Low } & \multicolumn{2}{|c|}{ Moderate } & & \\
\hline & $\mathbf{n}$ & $\%$ & $\mathbf{n}$ & $\%$ & $\mathbf{N}$ & $\%$ \\
\hline JHS & 1 & 16.7 & 5 & 83.3 & 6 & 100 \\
\hline SHS & 22 & 52.4 & 20 & 47.6 & 42 & 100 \\
\hline Bachelor & 1 & 50 & 1 & 50 & 2 & 100 \\
\hline \multicolumn{2}{|c|}{$\rho$ value } & \multicolumn{5}{|c|}{0.163} \\
\hline \multicolumn{2}{|c|}{$\begin{array}{l}\text { Conti-ngency } \\
\text { Coeffi-cient }\end{array}$} & \multicolumn{5}{|c|}{0.200} \\
\hline
\end{tabular}


Table 7. Correlation between Discipline and Productivity of Workers in the the Molding Machine Production Unit of PT. Bina Megah Indowood in 2019

\begin{tabular}{ccccccc}
\hline \multirow{2}{*}{ Discipline } & \multicolumn{4}{c}{ Productivity } & \multicolumn{2}{c}{ Total } \\
\cline { 2 - 6 } & \multicolumn{2}{c}{ Low } & \multicolumn{2}{c}{ Moderate } & & \\
\cline { 2 - 6 } & $\mathbf{n}$ & $\mathbf{\%}$ & $\mathbf{n}$ & $\mathbf{\%}$ & $\mathbf{N}$ & $\mathbf{\%}$ \\
\hline Low & 4 & 100 & 0 & 0 & 4 & 100 \\
Moderate & 19 & 46 & 22 & 54 & 41 & 100 \\
High & 1 & 20 & 4 & 80 & 5 & 100 \\
\hline \multicolumn{2}{c}{$\rho$ value } & & & 0.020 & & \\
\hline Conti-ngency & & & 0.328 & & \\
Coeffi-cient & & & &
\end{tabular}

on low, medium and high productivity. Table 7 is a cross tabulation table between discipline and productivity of workers in the molding machine production unit of PT. Bina Megah Indowood. The table shows the result of the statistical tests using the Spearman test with the result of the Sig. (2-tailed) $=$ 0.020 . This value is less than $\alpha(0.05)$. Thus, Ho is rejected, which means there is a correlation between discipline and productivity of the workers in the molding machine production unit of PT. Bina Megah Indowood. The resulting contingency coefficient is 0.328 , which indicates that the correlation between discipline and productivity is weak. Workers with moderate discipline can have low and moderate productivity.

\section{DISCUSSION}

\section{Individual Characteristics of Workers in the Molding Machine Unit of PT. Bina Megah Indowood}

According to National Population and Family Planning Board or BKKBN (2014), Indonesia's productive age range is 15 to 55 years. Meanwhile, productive-age workers are parts of the population who take part in ongoing employment activities. Productive-age workers are considered to be able to work in the labor process and bear the burden of those who fall into the category of unproductive population. Therefore, the workers in this study are productive age workers.

According to Siagian (2004), the increase in labor time is expected to increase work productivity. Length of work needs to be identified because it can be one indicator of workers' tendencies. The longer a worker works, the higher the productivity he has because the worker is more experienced in completing the tasks that have been entrusted to him. PT. Bina Megah Indowood does not have a specific agreement regarding the length of time a person has worked in that position, so several people are known to have worked since the company was first established (Siagian, 2004).

Furthermore, workers with higher education basically have broader insights, especially in the areas occupied at work. Education can be pursued through formal and informal channels. As the technology develops, the industry needs workers who can be fit-in with the latest technology. Nevertheless, workers in the molding unit at PT. Bina Megah Indowood do not need a certain level of education, so special knowledge and skills in working with machines are not required.

\section{Discipline of Workers in the Molding Machine Production Unit of PT. Bina Megah Indowood}

According to Agustini (2011) there are several indicators in work discipline, namely the level of attendance, work procedures, obedience to superiors, work awareness, and responsibilities. Some of these factors can be used as a means of mobilizing workers so that work can run well and smoothly. Therefore, the attitude of work discipline plays an important role in the process of achieving company's goals.

Work discipline is divided into three categories namely preventive, corrective and progressive discipline. Preventive discipline is the activity of encouraging workers to prevent violations of the rules. Corrective discipline is an activity to deal with violations, usually called a penalty or disciplinary action. Progressive discipline, on the other hand, gives more severe punishment for repeated violations. From these types of work discipline, workers are expected to be able to support and implement the regulations that have been set by the company so that the company's goals can be achieved easily (Izzah and Ardiani, 2016).

The analysis showsthat PT. Bina Megah Indowood workers' discipline level is moderate. This is because workers have unfavorable habits as they arenot punctual in starting their work and end their work ahead of the set hours. In addition, workers often steal time in the middle of work hours to smoke silently in the restroom. These bad habits are actions that cause the inconsistency of daily product outcomes. Even sometimes the product delivery does not meet the specified targets. 


\section{Productivity of Workers in the Molding Machinery Unit of PT. Bina Megah Indowood}

This study shows that molding machine workers rarely reach the predetermined targets. The number of products produced varies daily depending on the speed and accuracy of workers in getting wood into the machine. Adjusted with the company conditions, worker productivity is determined by comparing the capacity of molding machines and the quantity of products produced by workers.

Productivity is defined as a tangible result (product) produced by individuals or groups during a certain period of time in a work process. This means that the higher the number of products produced in a shorter time, the higher the level of productivity and vice versa(Sandi, 2016).

Correlation of Individual Characteristics and Productivity of Workers in the Molding Machine Production Unit of PT. Bina Megah Indowood

\section{Correlation between Age and Productivity of Workers in the Molding Machine Production Unit of PT. Bina Megah Indowood in 2019}

This study shows that there is no different productivity based on age of workers in the molding machine production unit of PT. Bina Megah Indowood. The result of the study is supported by a previous study conducted by Semmaila (2017) that there is no correlation between age and productivity because some companies may have more employees with productive age but there are no motivation and good discipline in themselves. However, the study is not in line with a previous study conducted by Farikha and Ardyanto (2017) stating that there is a relationship of age and work productivity, which means that good productivity is influenced by age.

\section{Correlation between Length of Work and Productivity of Workers in the Molding Machine Production Unit of PT. Bina Megah Indowood in 2019}

This study shows that there is no different productivity based on length of work of workers in the molding machine production unit of PT. Bina Megah Indowood. The result is similar to a study conducted by Verawati (2017) that there is no relationship between length of work and work productivity. The length of work of a person influences his performance of work. The longer a person works, the more experienced someone will be in doing his work and in adapting to his work and environment. The workforce will then adapt to the work and work environment. Increased work skills will make the human body more efficient in doing its work, so the workload will be reduced and the emergence of fatigue will be reduced.

However, the result of this study is not in line with a previous study conducted by Purbaya and Paskarini (2020) that there is a moderate relationship between length of work and work productivity. Longer work period can provide workers more work experience. It is also suggested that work experience is considered to be able to provide positive points in the calculation of income levels.

Correlation between Education and Productivity of Workers in the Molding Machine Production Unit of PT. Bina Megah Indowood in 2019

This study shows that there is no different productivity based on education of workers in the molding machine production unit of PT. Bina Megah Indowood.

The result of study is in line with a previous study conducted by Utomo (2018) stating that there is no significant correlation between education and work productivity because even though workers have high education but they have no desire to work, it is meaningless. However, the result of this study is not in line with a previous study conducted by Prabowo (2016), stating that there is a significant relationship between education and work productivity. This is because knowledge about specific work or work management learned during education can be applied at work, so that work productivity can increase.

Correlation between Discipline and Productivity of Workers in the Molding Machine Production Unit of PT. Bina Megah Indowood

The relationship between discipline and productivity is shown by workers who have low discipline and productivity. Some workers with moderate discipline have low productivity, but the majority have moderate productivity. Meanwhile, workers with high discipline do not automatically have high productivity.

The results of this study is supported with a previous study conducted by Siswadi (2016) stating that there is a significant influence between discipline and worker productivity. Workers who who have disciplined attitude can benefit the company because they can bring benefits to both themselves and the 
company. Discipline is easier to apply if workers voluntarily and consciously abide the rules that have been set. In addition, the companies must also make regulations that are made clear, and easy to understand. The regulations should also be fair to apply to the leaders and employees.

Discipline is the most important operational function of human resource management in a company. The better the level of employee discipline, the higher the level of productivity of these workers. Without implementing discipline for workers, it is difficult for companies to achieve optimal results.

One of the main factors in the decrease of the company productivity is poor work behavior of employees in terms of a lack of discipline, shown by workers who are often absent, fall asleep during working hours, or go home earlier than work hours. With human resources who are often undisciplined, work completion targets are never reached, which in turn affects the work productivity of the company (Sani, 2019).

Similar research conducted by Leonard (year) shows that work discipline has a positive and significant relationship with work productivity. In addition, discipline must be upheld in the organization or company because the proper attitude is able to realize the set goals. Discipline is the key to the success of an organization or company in achieving its goals (Sinaga, 2018).

Therefore, to achieve good work productivity, companies need to prepare programs for workers. This can be in the form of giving awards or incentives to workers with a good level of discipline. The policy can make workers improve discipline while reducing violations of existing regulations and can provide benefits for companies in the form of increased employee productivity (Laminia, 2018).

\section{CONCLUSION}

There is a correlation between discipline and work productivity. This is proven by the large number of workers in the molding machineproduction unit of PT. Bina Megah Indowood who have moderate discipline and have moderate productivity. An increase in the discipline of workers will be followed by an increase in the work productivity. However, it is found that there is no correlation of individual characteristics such as age, length of work, and education with work productivity.

\section{ACKNOWLEDGEMENTS}

Authors would like to thank the parents who always support and love in whatever condition as well as give financial support for this research and lovely sister and best friends who have provided unending inspiration

\section{REFERENCES}

Agustini, F. (2011) Manajemen Sumber Daya Manusia Lanjutan. Medan: Medanetera.

Asian Productivity Organization (2018) APO Productivitity Databook 2018.

Badan Kependudukan dan Keluarga Berencana Nasional (2014) Kerjasama Pendidikan Kependudukan Jalur Non Formal. Jakarta: Badan Kependudukan dan Keluarga Berencana Nasional .

Farikha, R. R. P. and Ardyanto, D. (2017) 'Hubungan Status Gizi, Karakteristik Individu Dengan Produktivitas Pekerja Sorting Dan Packing', The Indonesian Journal of Occupational Safety and Health, 5(1), pp. 71-80.

Firdaus, J. (2019) 'Analisis Disiplin, Budaya Kerja dan Motivasi Terhadap Produktivitas Kerja Karyawan di PT. Adi Satria Abadi Bantul', Jurnal EBBANK, 10(2), pp. 49-58.

Hasibuan, M. S. P. (2010) Manajemen Sumber Daya Manusia. Jakarta: PT. Bumi Aksara.

Iswandi Idris, Helviana Hasibuan, Doni Efriza, R. A. S. (2017) 'IBM Peningkatan Produktivitas Kelompok Usaha Roti "Nenot-Nenot" Kelurahan Suka Ramai Medan', Jurnal Teknovasi, 4(1), pp. 51-58.

Izzah, N. and Ardiani, I. (2016) 'Produktivitas Kerja Karyawan Pada Mechanical Division Pt Mulia Makmur Elektrikatama', Jurnal Administrasi Bisnis, 13(02), pp. 210-222.

Jamaludin, A. (2018) 'Hubungan Disiplin Kerja dan Motivasi terhadap Budaya Kerja pada CV. Panca Mandiri Jaya Karawang' Jurnal Manajemen \& Bisnis Kreatif, 3(2), pp. 224-237.

Laminia, D. (2018) 'Hubungan Motivasi Dan Masa Kerja Dengan Produktivitas Pekerja Di Home Industry', The Indonesian Journal of Occupational Safety and Health, 7(2), pp. 241-248.

Liyas, J. N. and Primadi, R. (2017) 'Pengaruh disiplin kerja terhadap kinerja karyawan pada bank perkreditan rakyat', Al Masraf: Jurnal Lembaga Keuangan dan Perbankan, 2(1), pp. 1-10. 
Prabowo, B. P. S. (2016) 'Pengaruh Tingkat Pendidikan Dan Penempatan Terhadap Produktivitas Kerja Karyawan Pada PT. Industri Kapal Indonesia, Bitung', Jurnal Berkala Ilmiah Efisiensi, 16(4), pp. 738-751.

Purbaya, H. and Paskarini, I. (2020) 'Correlation of Nutritional Status and Subjective Fatigue with the Productivity of Labourers Hubungan Status Gizi dan Kelelahan Subyektif dengan Produktivitas pada Pekerja Kuli', The Indonesian Journal of Occupational Safety and Health, 9(1), pp. 1-11.

Sandi, D. P. (2016) 'Analisis Hubungan Kompensasi Dan Motivasi Terhadap Produktivitas Kerja Karyawan Bagian Admin Di PT Dynamic Succes Globalindo', Fundamental Management Journal, :1(S) No.1(1), pp. 80-89.

Sani, N. (2019) 'Hubungan Antara Disiplin Kerja, Lingkungan Kerja Dan Etos Kerja Dengan Produktivitas Kerja Perawat Di Ruang Rawat Inap Rs Pertamina Bintang Amin Bandar Lampung Tahun 2018', Journal Ilmu Kedokteran dan Kesehatan, 6(3), pp. 186-193.

Sedarmayanti (2011) Tata Kerja dan Produktivitas Kerja. Edited by M. Maju. Bandung: CV. Mandar Maju.

Semmaila, B. (2017) 'Karakteristik Individu, Sosial Ekonomi, Budaya Dan Kesehatan Terhadap Produktivitas Kerja Karyawan Pada Industri Kecil Di Kota Makassar', EKUITAS (Jurnal Ekonomi dan Keuangan), 12(4), p. 549-567.

Siagian, S. P. (2004) Teori Motivasi dan Aplikasinya. Jakarta: Bina Aksara.

Sinaga, L. R. (2018) 'Hubungan Disiplin Kerja Terhadap Produktivitas Kerja Pegawai Dan Guru
Pada SMK SW. PGRI Kabupaten Toba Samosir', Tapanuli Journals, 1(1), pp. 121-126.

Siswadi, Y. (2016) 'Pengaruh Pelatihan dan Disiplin Terhadap Produktivitas Kerja Karyawan Pada PT. Jasa Marga Cabang (Belmera) Medan', Jurnal Ilmiah Manajemen dan Bisnis UMSU, 17(01), pp. 124-137.

Sunarsi, D. (2018) 'engaruh Motivasi dan Disiplin terhadap Produktivitas Kerja Karyawan pada PT. Nadi Suwarna Bumi', Jurnal SeMaRaK, 1(1), pp. 66-82.

Syafrina, N. (2017) 'Pengaruh Disiplin Kerja Terhadap Kinerja Karyawan', Eko dan Bisnis (Riau Economics and Business Reviewe), 8(4), pp. 1-12.

Utomo, S. B. (2018) 'Pengaruh Pendidikan dan Pelatihan Tenaga Kerja terhadap Produktivitas Kerja Karyawan Bagian Kasir pada Toserba Yogya di Kabupaten Majalengka', Syntax Literate: Jurnal Ilmiah Indnesia, 53(9), pp. 1689-1699.

Veitzhal, R. (2011) Manajemen Sumber Daya Manusia Untuk Perusahaan. Jakarta: PT. Raja Grafindo Persada Jakarta.

Verawati, L. (2017) 'Hubungan Tingkat Kelelahan Subjektif dengan Produktivitas pada Tenaga Kerja Bagian Pengemasan di CV Sumber Barokah', The Indonesian Journal of Occupational Safety and Health, 5(1), p. 51.

World Economic Forum (2018) Index Global Competitiveness. Geneva: World Economic Forum 